DOI: $10.19195 / 2082-8322.8 .14$

Tomasz Łukasz Nowak

Uniwersytet Wrocławski

\title{
Czy ryba może być z selera tak jak kaban z kury? O nazwach potraw na wegańskich blogach (i stołach)
}

[...] ludzie nie tylko jedzą pokarmy, ale także słowa.

Alfred Korzybski ${ }^{1}$

Prawdopodobnie każdy weganin przynajmniej raz w życiu usłyszał, że jego roślinny kotlet albo parówki nie są — odpowiednio - kotletem ani parówkami, bo - właśnie - są roślinne, a kotlety i parówki mogą być tylko z mięsa (choć $\mathrm{z}$ tymi drugimi $\mathrm{w}$ rzeczywistości bywa różnie). W każdym razie przepisy kulinarne na wegańskie (roślinne) potrawy, w nazwach których pojawia się element konotujący produkt odzwierzęcy, motywują część internautów do negatywnych komentarzy wyśmiewających społeczności wegetarian i wegan, w social mediach powstają strony ${ }^{2}$ publikujące deprecjonujące wegan treści, w końcu pojedynczy politycy zgłaszają sprzeciw wobec roślinnych mlek i sznycli ${ }^{3}$.

1 Alfred Korzybski, [hasło w:] Wikipedia, http://pl.wikipedia.org/wiki/Alfred_Korzybski (dostęp: 3.06.2017).

${ }^{2} \mathrm{~Np}$. dostępne na portalu społecznościowym Facebook.com: „Nie dla weganizmu”; „Beka z internetowych wegetarian”: www.fb.com/internetowiwege (dostęp: 30.05.2017); „Beka z wegan”; „Weganie to sekta. Rodzicu, chroń swoje dzieci”: www.fb.com/weganietosekta (dostęp: 30.05.2017).

${ }^{3}$ Niemiecki minister rolnictwa, Christian Schmidt, uważa, że nazwy wegańskich potraw nawiązujące do tradycyjnych potraw mięsnych wprowadzają konsumentów w błąd. Tego samego zdania są holenderscy deputowani: Erik Ziengs i Helma Lodders - weganizator.pl/2017/01/19/wege-news-odcinek-18/ (dostęp: 30.05.2017). Por. W Holandii walka o „wegetariański kotlet”, www.rmf24.pl/fakty/ swiat/news-w-holandii-walka-o-wegetarianski-kotlet,nId,2335562 (dostęp: 30.05.2017). 
Powtarzające się, nie tylko w sieci, dyskusje dotyczące problemu z nazwami wegańskich potraw/produktów nawiązujących do nazw potraw/produktów mięsnych (bądź nabiałowych) stały się inspiracją do szerszego nań spojrzenia i zbadania, czy rzeczywiście ryba (nie) może być z selera tak jak kaban(os) z kury?

Opierając się na analizie leksykograficznej wybranych nazw, funkcjach kulinarnych onimów oraz elementach semantyki ogólnej (generalnej), postaram się przedstawić motywacje autorów wybranych blogów ${ }^{4}$, prowadzące do (do)określenia roślinnych potraw nazwami konotującymi ich (od)zwierzęce pochodzenie.

\section{Tatar z łososia czy z pomidora?}

Kluczem do wyjaśnienia większości spornych nazw jest ich neosemantyzacja. Dokładniej - co obrazują przytoczone przykłady - mamy tu do czynienia z neosemantyzmami powstałymi w wyniku generalizacji zakresu wyrazów, tzn. rozszerzenia pierwotnego znaczenia leksemów. W ten sposób tatar, etymologicznie nazywający befsztyk z surowego mięsa wołowego czy końskiego ('potrawa z surowej polędwicy wołowej, siekanej lub mielonej, z przyprawami i często z surowym żółtkiem' ${ }^{5}$ ), aktualnie odnosi się również do podobnych wizualnie i/lub podobnie przyrządzanych potraw $\mathrm{z}$ surowych ryb ('befsztyk z mielonego surowego mięsa wołowego lub końskiego z surowym żółtkiem, przyprawami i dodatkami - cebulką, konserwowym ogórkiem itp. - dziś także podobna potrawa $\mathrm{z}$ mięsa ryby, najczęściej łososia lub śledzia' ${ }^{\text {'6 }}$. Idąc dalej - kolejna definicja tatara powinna zostać rozszerzona o jego roślinne odpowiedniki, czego przykładem są m.in. tatar $z$ pieczarek (W, 28.12.2012) ${ }^{7}$, tatar $z$ suszonych pomidorów (J, 29.12.2015) czy po prostu wegański tatar (E, 25.07.2015), przyrządzany $\mathrm{w}$ tym wypadku $\mathrm{z}$ wafli ryżowych i koncentratu pomidorowego. Ponadto, jak podkreśla na blogu Marta Dymek:

\footnotetext{
${ }^{4}$ Materiał badawczy zgromadziłem na podstawie przepisów potraw opublikowanych na blogach: „Jadłonomia” Marty Dymek (www.jadlonomia.com), „Wegan Nerd” Alicji Rokickiej (www.wegannerd. blogspot.com) oraz „erVegan” Eryka Wałkowicza (www.ervegan.com). Notabene wybrani autorzy wydają także własne książki kucharskie i pojawią się w programach telewizyjnych, a Marta Dymek prowadzi również swój autorski program kulinarny: Zielona Rewolucja Marty Dymek.

5 Tatar, [hasło w:] Inny słownik języka polskiego PWN, red. M. Bańko, t. 2, wyd. 2, Warszawa 2000, s. 812.

${ }^{6}$ Tatar, [hasło w:] M. Witaszek-Samborska, Studia nad słownictwem kulinarnym we wspótczesnej polszczyźnie, Poznań 2005, Słownik nazw potraw i napojów we współczesnej polszczyźnie, s. 385.

${ }^{7}$ Dla przejrzystości tekstu przy nazwach potraw pochodzących z wybranych blogów będę stosował zapis: (Nazwa bloga, Data publikacji przepisu), kolejno dla: „erVegan” - E, „Jadłonomia” — J, „Wegan Nerd" - W.
} 
Swoją wersję wegetariańskiego befsztyka tatarskiego opracował nawet słynny nowojorski szef kuchni Daniel Humm, który przygotowuje go z marchwi połączonej z kawałkami piklowanych jabłek, jabłkową musztardą, chrzanem oraz gorczycą ${ }^{8}$.

Jednym z popularniejszych neosemantyzmów w wegańskiej kuchni jest kotlet (i jego różne odmiany). Najprościej więc ujmując, kotlet to 'płaski smażony kawałek mięsa', 'potrawa z mięsa ubijanego lub mielonego, w formie placka, smażona na tłuszczu'10'. Leksykografowie łączą jego etymologię z francuskim côtelette oznaczającym 'żeberko'. $\mathrm{W}$ tym przypadku współczesne definicje uwzględniają już rozszerzenie znaczenia kotleta o jego roślinne wersje: 'potrawa $\mathrm{w}$ formie plastra lub placka wykonanego z mięsa (bitego, regionalnie też mielonego albo siekanego), ryb, ziemniaków, jaj, warzyw itp., zwykle panierowanego i smażonego na tłuszczu'11. W blogosferze (pełnoprawnie) królują więc: kotlety $z$ kalafiora $z$ sezamem, imbirem i cytryną (J, 16.08.2012), ziemniaczane kotlety $z$ sosem kokosowym (J, 10.03.2015), kotlety $z$ soczewicy i marchewki $z$ sosem cebulowym (W, 30.10.2011), kotlety $z$ tofu w nori (W, 12.06.2012) czy koperkowe kotlety $z$ młodej kapusty (E, 3.06.2015) i wiele innych.

O ile jednak znaczenie hiperonimu kotlet zostało rozszerzone o jego roślinne wersje, o tyle jego konkretne odmiany $\mathrm{z}$ definicji wciąż opierają się wyłącznie na produktach pochodzenia zwierzęcego. I mimo że w blogosferze znajdziemy np. niedzielny schabowy raz! (sojowy) (W, 13.02.2016), a autorzy blogów przyznają, że „[w]egański kotlet pod tytułem schabowy wcale nie jest kulinarnym oszustwem, jest pełnoprawnym i prawdziwym wegańskim daniem, które przypomina to mięsne"12, zgodnie ze słownikiem kotlet schabowy to nadal (tylko?) 'rozbity plaster schabu, panierowany i usmażony na złoty kolor' ${ }^{13}$. Analogicznie sprawa wygląda $\mathrm{z}$ kotletem mielonym, pulpetami i klopsem. W sieci można jednakże znaleźć przepisy na mielone kalafiorowe (J, 7.07.2016), spaghetti z pulpetami ( $z$ tofu) (J, 31.03.2014), wielowarzywne pulpety, które przygotujesz również z resztek (W, 25.05.2017), jaglane klopsiki z jarmużem (E, 10.01.2016), klopsiki z ciecierzycy - jak ze szwedzkiego bufetu (E, 23.03.2017), tofu-klopsy z mastem orzechowym (E, 20.11.2014) czy chrupiace medaliony z bakłażana (E, 9.07.2015). Tymczasem słowniki jednoznacznie definiują kotlet mielony jako 'owalny kotlet uformowany z mielonego mięsa, panierowany i usmażony ${ }^{14}$ (w niektórych przypadkach dookreślając,

${ }^{8}$ M. Dymek, Tatar z suszonych pomidorów, „Jadłonomia”, www.jadlonomia.com/przepisy/tatar-zsuszonych-pomidorow/ (dostęp: 30.05.2017).

${ }^{9}$ Kotlet, [hasło w:] Inny słownik..., t. 1, Waszawa 2000, s 693.

10 Kotlet, [hasło w:] Słownik Języka Polskiego SJP, www.sjp.pl/kotlet (dostęp: 30.05.2017).

11 Kotlet, [hasło w:] Stownik nazw potraw..., s. 276.

12 E. Wałkowicz, Czy wegetarianie udaja i dlatego jedza kotlety? - czyli więcej o wegańskich parówkach, tatarze i sojowej wędlinie, „erVegan”, www.ervegan.com/2015/07/czy-wegetarianie-udaja-i-dlatego-jedzakotlety-czyli-wiecej-o-weganskich-parowkach-tatarze/ (dostęp: 30.05.2017).

${ }^{13}$ Kotlet schabowy, [hasło w:] Inny słownik..., t. 1, s. 693.

${ }^{14}$ Kotlet mielony, [hasło w:] Inny słownik..., t. 1, s. 693. 
że zwykle jest to mięso wieprzowe ${ }^{15}$ ), klopsy jako 'okrągłe kotlety z mielonego mięsa, duszone, zwykle podawane $\mathrm{w}$ sosie' ${ }^{16}$, pulpeta jako 'mielone mięso, ryby lub podroby $\mathrm{z}$ dodatkiem tłuszczu, bułki tartej, jaj i przypraw, uformowane w kulkę i ugotowane, podawane jako dodatek do zup albo danie główne' ${ }^{17}$, a medalion jako 'okrągły lub owalny kotlet $\mathrm{z}$ mięsa cielęcego, wołowego, drobiu lub z ryby, smażony bez panierki ${ }^{18}$.

\section{O nieistnieniu hamburgerów z ryby ani z soi}

Wraz z modą na burgery, zwłaszcza te w wersji slow (food), która utrzymuje się na polskim rynku od kilku dobrych lat ${ }^{19}$, kojarzony z prostotą i tradycją kotlet zaczął ustępować miejsca nowoczesnemu, zgodnemu $\mathrm{z}$ zachodnimi trendami burgerowi, który z powodzeniem zastępuje również swój fastfoodowy pierwowzór - hamburgera. Ten ostatni (choć historycznie pierwszy) pierwotnie nazywał mieszkańca Hamburga, ale zapożyczony przez Amerykanów (najpierw jako Hamburger steak, czyli 'befsztyk hamburski' ${ }^{20}$, a następnie skrócony do leksemu hamburger) objął swoim znaczeniem 'kotlet $\mathrm{z}$ mielonej wołowiny, podawany na gorąco z cebulą i keczupem w rozciętej okrągłej buł$\mathrm{ce}^{21}$. I o ile definicje hamburgera podkreślają, że podstawą potrawy jest kotlet $\mathrm{z}$ (mielonej) wołowiny (np. 'niepanierowany, smażony w tłuszczu płaski kotlet z mielonej wołowiny, podawany zwykle w rozciętej bułce $\mathrm{z}$ dodatkami' ${ }^{22}$ ), o tyle - jak zauważa Roman Ociepa w Paru uwagach na temat anglicyzmu burger — „[w] wyniku błędnego podziału leksemu hamburger na człony ham (ang. 'szynka') i burger stało się możliwe utworzenie leksemu cheeseburger" 23 (oznaczającego jeszcze: "kotlet z mielonej wołowiny, podawany wraz z roztopionym serem w rozciętej bułce ${ }^{24}$ ) oraz kolejnych, zastępujących już główny (!) składnik innymi, np. fishburger ('smażony filet rybny, podawany w okrągłej bułce $\mathrm{z}$ warzywami i sosem ${ }^{25}$ ), chickenburger ('burger drobiowy ${ }^{26}$ ), soyaburger/soja-

${ }^{15}$ Kotlet mielony, [hasło w:] Słownik nazw potraw..., s. 276.

${ }^{16}$ Klopsy, [hasło w:] Inny słownik..., t. 1, s. 629.

17 Pulpet, [hasło w:] Słownik nazw potraw..., s. 346.

18 Medalion, [hasło w:] Słownik nazw potraw..., s. 299.

19 M. Glinka, Burgeromania czyli burgery w natarciu, „Restaurantica.pl”, www.restaurantica. pl/2012/10/24/burgermania-czyli-burger-w-natarciu/ (dostęp: 1.06.2017). Zob. też Burgery podbijaja polskie podniebienia, „WP Finanse”, www.finanse.wp.pl/burgery-podbijaja-polskie-podniebienia-6114649481324673a (dostęp: 30.05.2017).

${ }^{20}$ R. Ociepa, Parę uwag na temat anglicyzmu burger, „Poradnik Językowy” 1998, nr 3, s. 32-36.

${ }^{21}$ E. Mańczak-Wohlfeld, Angielskie elementy leksykalne w języku polskim, Kraków 1994, s. 59, cyt. za: R. Ociepa, op. cit., s. 32.

${ }^{22}$ Hamburger, [hasło w:] Słownik nazw potraw..., s. 252.

23 R. Ociepa, op. cit., s. 32.

${ }^{24}$ E. Mańczak-Wohlfeld, op. cit., s. 32.

${ }^{25}$ Fishburger, [hasło w:] Stownik nazw potraw..., s. 237.

${ }^{26}$ Chickenburger, [hasło w:] Słownik nazw potraw..., s. 215. 
burger ('burger z soi ${ }^{27}$ ) czy tofuburger ('burger z serka tofu'28) itd. W rzeczywistości z hamburgera, którego podstawą był wołowy kotlet (przez co konstrukcje hamburger rybny czy hamburger sojowy R. Ociepa uważa z definicji za sprzeczne, niepoprawne ${ }^{29}$ ), pozostał burger ('płaski, okrągły kotlet z mielonej wołowiny — drobiu, ryby, warzyw itp. - smażony lub grillowany, zwykle podawany w bułce $\mathrm{z}$ dodatkami ${ }^{30}$ ), którego podstawę stanowi przecięta bułka $\mathrm{z}$ odpowiednim kotletem, na rodzaj którego już w nazwie potrawy wskazuje jego odpowiednie dookreślenie, np. burgery botwinkowe (J, 28.05.2014), burger $z$ szarpanej czerwonej kapusty w piwie (W, 23.01.2017) czy stek-burgery z kalafiora (E, 29.10.2016).

Innym anglicyzmem (wciąż nieopisanym w literaturze) wartym wspomnienia jest nugget (przyjmujący w języku polskim również zdepluralizowaną formę: nuggets). $\mathrm{Z}$ definicji nazywa on 'mały, panierowany kotlecik z piersi drobiu, smażony w głębokim tłuszczu, rozpowszechniony przez restaurację McDonald's' ${ }^{31}$. Anglojęzyczna wersja Wikipedii zaznacza, że sieci restauracji (typu fast food), jak McDonald's czy szwedzki Max Hamburgare, mają w ofercie również wersje roślinne nuggetów (bądź nuggetsów), przygotowywane kolejno z fasoli (Garden McNuggets) i z ciecierzycy (na wzór falafela $)^{32}$. Adam Wolański w „Poradach językowych” na stronie internetowej Słownika języka polskiego PWN zaznacza także spotykane w uzusie nieliczne połączenia typu nuggety wegetariańskie ${ }^{33}$. Współczesne definicje nuggetów powinny zatem zostać rozszerzone o roślinne warianty tychże, tym bardziej że w polskiej blogosferze od dawna pojawiają się przepisy na ich wegańskie wersje, np. nuggetsy $z$ cukinii $z$ ostrym sosem majonezowym (W, 31.07.2016), pieczone nuggetsy $z$ pieczarek (E, 10.03.2015) czy rodzime odpowiedniki tychże, czyli skrzydełka $z$ boczniaków (E, 22.05.2016) lub pieczone skrzydełka $z$ kalafiora (E, 19.05.2015).

\section{No to klops! Albo pulpet...}

Pisząc o kotletach, nie sposób nie wspomnieć o stekach. Stek (etymologicznie z języka staronordyckiego: steik - 'smażyć) nazywa 'potraw[ę] z kawałka mięsa krojonego w poprzek włókien mięśniowych lub ryby krojonej w poprzek kręgosłupa. Mięso na

27 Sojaburger, [hasło w:] Słownik nazw potraw..., s. 367.

28 Tofuburger, [hasło w:] Stownik nazw potraw..., s. 386.

29 Zob. R. Ociepa, op. cit., s. 34, przypis 4.

30 Burger, [hasło w:] Stownik nazw potraw..., s. 208.

${ }^{31}$ Nuggets, [hasło w:] Stownik nazw potraw..., s. 315.

32 Chicken nugget, [hasło w:] Wikipedia, http.//en.wikipedia.org/wiki/Chicken_nugget (dostęp: 31.05.2017).

${ }^{33}$ Nugget, [hasło w:] Słownik języka polskiego PWN, www.sjp.pwn.pl/slowniki/nugget.html (dostęp: 31.05.2017). 
steki zazwyczaj jest grillowane lub smażone z odrobiną oleju'34. Definicja ta nie została jak dotąd rozszerzona o roślinne warianty potrawy, choć w sieci bez problemu można znaleźć przepisy m.in. na marynowane steki portobello (E, 29.05.2017), steaki z czerwonej kapusty (W, 5.02.2015) i steki $z$ kalafiora $z$ marchewkowym puree (W, 2.02.2017). Istotna w tym przykładzie jest za to nominatywno-deskryptywna funkcja kulinarnych onimów; nazwy potraw bowiem nie tylko informują, z jakich składników ta została zrobiona, lecz także w jaki sposób. Dzięki temu — jak zauważa Małgorzata Dawidziak-Kładoczna - nawet tak skąpa informacyjnie nazwa, jak „Stek à la tępa strzała $w$ zadzie bizona sugeruje sposób przyrządzenia mięsa (stek)"35. Oznacza to, że przez odpowiedni dobór leksemów w nazwie (np. steki z kalafiora albo steaki z czerwonej kapusty) odbiorca jest w stanie wyobrazić sobie np. sposób cięcia warzywa, obróbkę termiczną (tj. w tym wypadku smażenie bądź grillowanie) oraz finalny wygląd dania.

$\mathrm{Z}$ drugiej strony, nieodpowiednio stworzony onim może wprowadzić potencjalnego odbiorcę w błąd. Dla przykładu - podane wcześniej definicje kotleta mielonego, klopsa i pulpetów różnicują je pod kątem ich przygotowania (tzn. mielony jest smażony, klops - zwykle duszony, ewentualnie smażony ${ }^{36}$, a pulpet - gotowany). Tymczasem zaprezentowane na wegańskich blogach wybrane przepisy na pulpety - np. pulpety $z$ dyni z kuminem (W, 23.10.2015), pulpety $z$ brokuła i ryżu z czosnkiem i sosem cytrynowym z tahini (W, 28.03.2016) czy pulpety na włoska nute (W, 10.04.2017) — zgodnie $\mathrm{z}$ intencją autorki powinny zostać kolejno: usmażone, usmażone i upieczone, co z definicji zbliża je do klopsów/klopsików. Można byłoby się więc zastanawiać, czy styczność nazwy pulpetów $z$ dyni jedynie z potencjalnym wyglądem tychże wystarcza, by móc nazywać je pulpetami? Z drugiej strony — jak zauważa Anna Dąbrowska - „nie ma ścisłych reguł odnoszących się do tworzenia nazw nowo wymyślonych dań, można więc popuścić wodze fantazji”37, a dzięki performatywnej funkcji języka pulpety, nawet gdyby w rzeczywistości okazały się klopsikami, raz mianowane przez ich autora/autorkę pozostaną pulpetami już do końca (posiłku).

34 Stek, [hasło w:] Wikipedia, http://pl.wikipedia.org/wiki/Stek_(potrawa) (dostęp: 1.06.2017).

${ }^{35}$ M. Dawidziak-Kładoczna, Nazwy potraw a marketing. Perswazyjne środki językowe we wspótczesnym nazewnictwie gastronomicznym, „Prace Naukowe Akademii im. Jana Długosza w Częstochowie. Filologia Polska. Językoznawstwo" 2013, z. 9, s. 98.

${ }^{36}$ W rzeczywistości (i w sieci) różnica miedzy klopsami a pulpetami wcale nie jest taka wyraźna, co na portalach kulinarnych pokazują liczne pytania (i równie liczne próby odpowiedzi), co (nie) jest klopsem, a co (nie) jest pulpetem. Zob. np. www.poloniainfo.se/forum/temat.php?temat=27889 (dostęp: 3.06.2017).

37 A. Dąbrowska, O językowym zachowaniu się przy stole. Dlaczego upiększamy nazwy potraw?, [w:] Oczywisty urok biesiadowania, red. P. Kowalski, Wrocław 1998, s. 249. 


\section{Bezserowy à la sernik zwany tofurnikiem}

Obok (chyba najliczniejszej, jeśli chodzi o nazwy wegetariańskich potraw) grupy neologizmów semantycznych warto też zwrócić uwagę na neologizmy słowotwórcze. Wyróżnić tutaj należy przede wszystkim:

- tofucznicę, czyli potrawę przypominającą jajecznicę, na bazie rozdrobnionego i smażonego tofu z dodatkiem czarnej soli (kala namak), która nadaje daniu charakterystyczny jajeczny posmak, np. tofucznica z jarmużem i pieczarkami (E, 20.07.2014), tofucznica z czosnkiem niedźwiedzim (W, 18.04.2017);

- tofurnik ${ }^{38}$, czyli ciasto, którego wygląd, smak i konsystencja nawiązują do klasycznego sernika, np. warstwowy tofurnik, czyli sernik wegański na zimno z malinami (W, 8.09.2016), tofurnik kokosowy z mango (J, 14.08.2014);

- jagielnik, podobnie jak tofurnik naśladuje sernik, ale zrobiony jest z kaszy jaglanej;

- nernik, tak jak dwa poprzednie, wyglądem, smakiem i konsystencją naśladuje sernik, lecz przyrządzany jest z orzechów nerkowca, np. nernik z lawendą (W, 29.03.2013);

- sojonez, czyli sojowy majonez przygotowywany na bazie mleka sojowego;

- seleryba/seleroryba, czyli plastry selera owinięte w glony (zwykle nori), usmażone bądź upieczone, przeważnie opanierowane, np. bezrybny filet $z$ selera - seleroryba (E, 16.11.2014), seleryba (J, 10.12.2014).

Warto się również przyjrzeć konstrukcjom bądź pojedynczym elementom w tych nazwach roślinnych potraw, które już na poziomie graficznym treści sugerują, że potrawa jedynie nawiązuje do swojej klasycznej, tradycyjnej wersji. Po pierwsze, mam na myśli onimy ze znaną nie tylko w kuchni wegańskiej francuską formułą à la ('wykonany tak, by przypominał kogoś lub coś, np. cielęcina à la flaczki ${ }^{39}$ ), np. seler à la ryba po grecku (W, 12.12.2014), tofu à la śledź (W, 23.12.2013), wegański „ser” à la rikotta $z$ mleka sojowego (W, 2.06.2013). Po drugie, wyróżnieniu w pełni roślinnego charakteru dania służy wpisywanie w cudzysłów tych elementów nazwy potrawy, które z definicji sugerują odbiorcom ich odzwierzęce pochodzenie, np. orzechowy "sernik” z białej fasoli (W, 21.04.2013), pasztet $z$ soczewicy i grzybów $z$ „tluszczykiem” do smarowania (W, 20.04.2017), zupa z kapusty włoskiej z „wędzonką" (W, 8.01.2017).

Trzecią konstrukcją są (ciekawe w swojej logice) złożenia z przedrostkiem bez-, np. bezjajeczna pasta z curry (J, 6.04.2014), sos bezrybny (J, 11.05.2014), wspomniany już bezrybny filet $z$ selera $(\mathrm{E}, 16.11 .2014)$ czy $\left(\right.$ bez)ser $z$ orzechów ${ }^{40}$. W rzeczywisto-

38 'Wegański sernik, do którego przygotowania używa się tofu zamiast sera twarogowego'. Zob. Tofurnik, [hasło w:] Obserwatorium Językowe Uniwersytetu Warszawskiego. Najnowsze Słownictwo Polskie, www.nowewyrazy.uw.edu.pl/haslo/tofurnik.html (dostęp: 1.06.2017).

${ }_{39}$ À la, [hasło w:] Słownik języka polskiego PWN, www.sjp.pwn.pl/sjp/a-la;2549349.html (dostęp: 1.06.2017).

40 (Bez)ser z orzechów - idealny do wszystkiego (wegański i beznabiałowy), „Vegewiórka, czyli kuchnia roślinna”, www.vegewiorka.blogspot.com/2017/04/bezser-z-orzechow-idealny-do.html (dostęp: 1.06.2017). 
ści bowiem nazwy te paradoksalnie sugerują swoim wegańskim odbiorcom jajeczny smak bezjajecznych potraw, rybny bezrybnych czy serowy tych bezserowych (,Jednym z jego [Vegan Dad - T.Ł.N.] najgenialniejszych przepisów jest pomysł na... sos bezrybny, czyli wegetariańską wersję klasycznego sosu rybnego”41; „A na początek [...] wegańska bezjajeczna pasta $\mathrm{z}$ dodatkiem curry - czyli pasta $\mathrm{z}$ tofu, która za sprawą czarnej soli pachnie i smakuje zupełnie jak ta przygotowana z gotowanych jajek"42). Ponadto w 2017 r. na polskim rynku pojawił się „Bezmięsny mięsny” sklep, który oferuje swoim klientom w pełni roślinne mięso, tzw. vmięso, np. boczek roślinny albo roślinne peperoni ${ }^{43}$.

Kolejnym sposobem na podkreślenie roślinnego pochodzenia potrawy jest dodanie przed jej nazwą litery „v". Jest to jak dotąd najrzadziej spotykana w polskiej blogosferze konstrukcja i zwykle dotyczy określonych grup produktów, takich jak nabiał (vnabiał) czy mięso (vmięso), np. szarpane vmięso młodego chlebowca na groźnie ostro! (W, 20.04.2016).

Warto pamiętać również o klasycznych już wyrażeniach z użyciem przymiotnika wegański lub skrótem wege/vege oraz złożeniach ${ }^{44} \mathrm{z}$ cząstką wege-/vege-, np. wegański parmezan z migdałów (J, 25.02.2013), wegański sos tatarski (J, 18.03.2016) albo wege rosół $z$ makaronem $z$ marchewki (W, 23.01.2016) czy wegepyszności (E, 17.11.2015) i najlepsze wegeburgery na świecie (J, 27.03.2012).

\section{Nad rozlanym... napojem sojowym}

Wegańskie potrawy to nie tylko vmięso, lecz także vnabiał; to wegańskie mleka, kefiry, śmietany i sery. Tymczasem na początku artykułu wspomniano o politykach, którzy uznali, że nazywanie roślinnych napojów mlekiem wprowadza konsumentów w błąd, choć na opakowaniu leksem mleko zwykle nie występuje samodzielnie ${ }^{45}$, a tylko w wy-

${ }^{41}$ M. Dymek, Sos bezrybny, „Jadłonomia”, www.jadlonomia.com/przepisy/sos-bezrybny/ (dostęp: 1.06.2017).

${ }^{42}$ M. Dymek, Bezjajeczna pasta z curry, „Jadłonomia”, www.jadlonomia.com/przepisy/bezjajeczna-pasta-z-curry/ (dostęp: 1.06.2017).

${ }^{43}$ Opis działalności „Bezmięsnego mięsnego” i jego oferta dostępne są na www.bezmiesnymiesny.pl (dostęp: 1.06.2017).

${ }^{44}$ Dyskusyjne wciąż podejście do takich cząstek jak eko-, wege- nie pozwala jednoznacznie zakwalifikować tych złożeń do złożeń prefiksoidalnych (choć ku tym autor artykułu by się skłaniał.). Zob. I. Burkacka, Klasyfikacja słowotwórcza nowszych zapożyczeń, „Linguistica Copernicana” 2010, nr 2 (4), s. 237.

45 Warto też zaznaczyć, że zgodnie z art. 2. ust. 1. Rozporządzenia Komisji (EWG) NR 1898/87 z dnia 2 lipca 1987 r. w sprawie ochrony oznaczeń stosowanych w obrocie mlekiem i przetworami mlecznymi nazwa mleko oznacza 'wyłącznie zwykłą wydzielinę piersiową, otrzymywaną z jednego lub więcej udojów, bez żadnych dodatków ani ekstrakcji’ oraz że - zgodnie z art. 3. ust. 1. akapit 2 - „przepisu tego nie stosuje się do oznaczania produktów, których dokładny charakter jest jasny dzięki tradycyjne- 
rażeniu z przymiotnikiem je dookreślającym, np. mleko sojowe czy mleko kokosowe. $\mathrm{Z}$ pomocą przychodzą więc definicje, które mlekiem nazywają 'biały, nieprzezroczysty płyn wytwarzany przez gruczoły mleczne krów, kóz i niektórych innych zwierząt hodowlanych, służący ludziom jako pożywienie" ${ }^{46}$, ale też 'białawy płyn zawarty w komórkach niektórych roślin, np. w owocach i nasionach ${ }^{37}$. Tymczasem napój to najogólniej, po prostu, 'płyn przeznaczony do picia ${ }^{48}$. Mając zatem do wyboru konotujące z konkretną barwą, smakiem, a przez to i z pewnymi sytuacjami (np. z dzieciństwa) mleko i bardzo ogólny, niewpływający już tak dobrze na zmysły odbiorcy albo przywołujący na myśl słabszy jakościowo produkt - napój, nie powinien dziwić fakt, że do ulubionej kawy zamiast np. napoju sojowego weganie wolą dolewać domowe mleko migdałowe (E, 2.07.2014), domowe mleko jaglane (W, 8.02.2017), mleko z nerkowców w 5 minut (E, 16.08.2015) albo słodkie mleko owsiane $z$ woda różana (W, 8.02.2015).

Definicje przetworów mlecznych (kefiru, śmietany, sera i twarogu) jako produktów powstałych na bazie mleka współcześnie nie uwzględniają ich wegańskich wariantów. Ciekawe jest jednak, że np. ricotta, pierwotnie nazywająca 'włoski, niesolony wiejski twarożek z owczego mleka ${ }^{49}$, dziś - przez generalizację jej znaczenia — nazywa również 'miękki, niedojrzewający ser zwarowy, produkowany we Włoszech z serwatki pozostającej po serach podpuszczkowych (z mleka koziego, krowiego lub owczego $)^{50}$. Być może wkrótce definicja ta zostanie rozszerzona również o mleko sojowe (i inne roślinne), albowiem — jak pokazuje polska blogosfera — weganie mają już swoje przepisy na:

— kefir: wegański kefir (W, 12.02.2014);

-śmietanę:śmietanaztofu(W,12.08.2016), domowaśmietanaryżowa(W,28.10.2013);

- twaróg: twarożek z migdałów (J,7.05.2013), kwaśny twaróg migdałowy (E, 1.03.2015);

- parmezan: wegański parmezan z migdałów (J, 25.02.2013), parmezan z nerkowców (E, 30.06.2014);

- ricottę: wegański „ser” à la rikotta z mleka sojowego (W, 2.06.2013);

— ser topiony: „serek topiony” z ciecierzycy (W, 24.08.2012);

- ser pleśniowy: Gorgon ser sojowy a’la pleśniowy (od „Serotoniny” ${ }^{51}$ ) (W, 30.11.2016);

- ser feta: Tofu Feta (J, 9.08.2015)

mu stosowaniu i/lub kiedy oznaczenia są konkretnie stosowane do opisania charakterystycznej jakości produktu" - EUR-Lex, www.eur-lex.europa.eu/legal-content/PL/TXT/?uri=celex\%3A31987R1898 (dostęp: 2.06.2017).

${ }^{46}$ Mleko, [hasło w:] Inny słownik..., t. 1, s. 878.

47 Ibidem, s. 878.

${ }^{48}$ Napój, [hasło w:] Inny słownik..., t. 1, s. 945.

${ }^{49}$ Ricotta, [hasło w:] Stownik nazw potraw..., s. 350.

${ }^{50}$ Ricotta, [hasło w:] Wikipedia, http://pl.wikipedia.org/wiki/Ricotta (dostęp: 1.06.2017).

51 „Serotonina” to funkcjonująca na polskim rynku od $2016 \mathrm{r}$. firma produkująca rzemieślnicze sery roślinne, której oferta obejmuje „wszelkie rodzaje wegańskich serów — od miękkich i delikatnych twarożkowych, poprzez twarde i aromatyczne, aż po intensywne w smaku "pleśniaki«". Zob. „Serotonina”, http://web.facebook.com/serotoninacheeze/about/ (dostęp: 2.06.2017). 
— czy nawet ser żółty: cudownie ciagnacy się ser... z ziemniaka (W, 27.09.2015), ziołowy ser z ziemniaka (W, 1.06.2017).

\section{Nazwa rozpływająca się w ustach}

Alfred Korzybski, twórca semantyki ogólnej (ang. general semantics) ${ }^{52}$, uważał, że „ludzie nie tylko jedzą pokarmy, ale także słowa, i że smak tych pierwszych często zdominowany jest smakiem drugich" ${ }^{53}$. Poprzez odpowiedni dobór (i połączenie) leksemów możemy bowiem wpłynąć na świadomość odbiorcy i - w tym wypadku przede wszystkim - na jego zmysły smaku (pobudzając łaknienie), węchu, wzro$\mathrm{ku}$, a nawet dotyku i temperatury. Również Małgorzata Witaszek-Samborska, pisząc o nazwach sensorycznych odwołujących się do cech organoleptycznych potraw, podkreśla, że ich zadaniem jest „pozytywne pobudzanie zmysłów wzroku [...] i smaku [...] jako najwrażliwszych na bodźce kulinarne, ale także węchu, dotyku i słuchu odbiorcy" 54 . Warto przy tym zaznaczyć, że obok przeważnie używanych w kulinarnych onimach określeń wyrażających smak, strukturę/konsystencję potrawy, jej temperaturę, barwę, kształt, wielkość itp. w omawianych w tym artykule przypadkach taką funkcję pełnią już same porównania do wybranych potraw (od)zwierzęcych. To znaczy, że wyobraźnia odbiorcy uruchamiana jest bezpośrednio (przede wszystkim!) przez konotacje do niewegańskich dań, a przez to dopiero (pośrednio) przez cechy do tych dań przypisane (np. smak, konsystencja, sposobu przyrządzenia) ${ }^{55}$. Twórcy „Bezmięsnego mięsnego” wyjaśniają to następująco:

„Mięsne” nazwy [produktu - T.Ł.N.] pomagają roślinożercom wyobrazić sobie, jaki może być w smaku czy jak wykorzystać go do ulubionych przepisów jako zamiennik produktów zwierzęcych. Z kolei mięsożercom pozwalają znaleźć bezmięsne odpowiedniki ich ulubionych produktów. Nazwy są po prostu drogowskazem, bez którego ciężko byłoby połapać się w świecie roślinnych „mięs”"56.

Wybór nazwy determinowany jest również tym (co niejednokrotnie powtarza się w społeczności wegan), że „przechodząc na wegetarianizm czy weganizm, nie trzeba już rezygnować z ulubionych smaków" ${ }^{57}$. Próbując więc odpowiedzieć na pytanie, po co weganom mięsne/nabiałowe nazwy roślinnych potraw, możemy przeczytać, że:

52 Semantyka ogólna, [hasło w:] Wikipedia, http://pl.wikipedia.org/wiki/Semantyka_ogólna (dostęp: 3.06.2017).

${ }^{53}$ http://pl.wikipedia.org/wiki/Alfred_Korzybski (dostęp: 3.06.2017).

${ }^{54}$ M. Witaszek-Sambroska, Studia nad słownictwem kulinarnym we współczesnej polszczyźnie, Poznań 2005, s. 150.

55 Por. przewaga onimu mleko nad napojem w rozdziale: Nad rozlanym... napojem sojowym.

56 Sklep mięsny bez mięsa!, „Label Magazine”, www.label-magazine.com/sklep-miesny-bez-miesa-ezp-5933.html (dostęp: 3.06.2017).

57 A. Michnicka, Wegański schabowy, czyli po co nam „mięsne” nazwy roślinnych potraw?, www.igimag. pl/2017/04/weganski-schabowy-czyli-po-co-nam-miesne-nazwy-roslinnych-potraw/ (dostęp: 3.06.2017). 
W przypadku przeróbek potraw ze składnikami odzwierzęcymi nadanie oryginalnej nazwy jest niezbędne, by ludzie wiedzieli, że zostały przygotowane w wolny od okrucieństwa sposób. Jeśli zamieszczę w Internecie przepis na „sałatkę z ciecierzycy” (a nie „sałatkę z ciecierzycy o smaku tuńczyka”), skąd inni będą mogli wiedzieć, że miałam zamiar odtworzyć smak sałatki czy kanapki z tuńczykiem, tak często niegdyś uwielbianej przez obecnych wegan i wegetarian? ${ }^{58}$

Możemy powiedzieć tak: „Wczoraj jadłam roślinny zamiennik burgera posypany imitacją sera i pseudobekonem [...]”. Należy [jednak] unikać takich słów, jak „zamiennik”, „alternatywa”, „imitacja”, „pseudo-”, ponieważ wegańskie jedzenie jest prawdziwym pokarmem, a nie jakąś gorszą, wymyśloną wersją pokarmów odzwierzęcych ${ }^{59}$.

Konsumentom mógłby się nie spodobać „smażony płaski placek (czy możemy użyć słowa „placek”?) o nieokreślonym kształcie z białka pszennego i soi w bułce tartej”60.

Tuńczykowa sałatka z ciecierzycy, chrupiące skrzydełka z boczniaków, bekon z kokosa, pizza z sojowym pepperoni, jajecznica $\mathrm{z}$ kaszy jaglanej, beza $\mathrm{z}$ aquafaby (czyli wody po gotowaniu roślin strączkowych) - dokładnie wiemy, jakich smaków możemy spodziewać się po tych daniach. I życie jest prostsze ${ }^{61}$.

Potrawy takie jak zapiekana pieczeń seitanowa z pieczarkami, lasagne z nerkowcowym beszamelem, bezmięsne zimne nóżki, czy skrzydełka z kalafiora to po pierwsze świetne żarcie, ale też urozmaicenie jadłospisu, które jednocześnie pomaga przypomnieć sobie smaki dawno niejedzonych potraw, czy też zwyczajnie nacieszyć oko i podniebienie, po prostu ${ }^{62}$.

Wypowiedzi te pokazują trzy istotne funkcje omawianych nazw. Po pierwsze, co podkreśla A. Dąbrowska, nazwy potraw powinny „wzbudzać tęsknotę za dobrym jadłem"63, a w tym wypadku - za smakiem nabiału czy mięsa w ogóle. Smak tychże zaś powinien tę tęsknotę ostatecznie wynagrodzić.

Po drugie, można zauważyć, że są pewne „potrawy, których nazwy wywołują cały ciąg skojarzeń z dzieciństwem, domem, zaspokojeniem głodu, miłym towarzystwem, i takie, które wspominane są jak najgorzej i dlatego nie są jadane" ${ }^{64}$. Stąd wielokrotne odwoływanie się w wypowiedziach wegan (i wegetarian też) do czasów (i sentymentów), kiedy spożywali mięso i produkty nabiałowe (co motywuje ich do odnalezienia ulubionych smaków pośród roślinnych produktów).

Po trzecie, „pożywienie, a zwłaszcza składające się na nie potrawy, jak i wzory zachowań, zajmuje szczególne miejsce, będąc jednym ze znaków tożsamości grupowej”'65. Oznacza to, że potrawy, ich nazwy, pomagają w tworzeniu społeczności wegan, umacniają ją oraz pozwalają rozbudować o nowych członków, którym - przez tęsknotę za smakiem

${ }^{58}$ D. Gruba, Czy nazwa ma znaczenie?, „Otwarte Klatki”, www.otwarteklatki.pl/czy-nazwa-ma-znaczenie/ (dostęp: 3.06.2017).

${ }^{59}$ Ibidem.

${ }^{60}$ Odpowiedź na próbę zakazu nazywania sznyclem jego roślinnej wersji - A. Michnicka, op. cit.

${ }^{61}$ Ibidem.

62 E. Wałkowicz, op. cit.

63 A. Dąbrowska, op. cit., s. 249.

${ }^{64}$ Ibidem.

65 Z. Szromba-Rysowa, Pożywienie jak znak identyfikacji kulturowej. Z etnograficznych badań na Podhalu, „Studia Małopolskie” 1997, nr 1, s. 71. 
mięsa/nabiału lub wspomnień i sentymentów - łatwiej będzie zmienić dotychczasowe przyzwyczajenia żywieniowe na dania inspirowane ich ulubionymi smakami.

Na koniec należy podkreślić, że nie bez znaczenia w tym przypadku wydaje się być (badany) kanał komunikacji - blog. Nazwy potraw przez swoje funkcje: poznawczą (informują m.in. o tym, z jakich składników i w jaki sposób powstało danie), identyfikacyjną (pozwalają odróżnić jedną potrawę od innej) i impresywną/perswazyjną (pobudzają apetyt odbiorcy i jego kulinarną wyobraźnię) mają „kształtować postawy i przekonania adresata, przyciągnąć jego uwagę, zaintrygować" 66 i nakłonić do wypróbowania przepisu. Wybór odpowiedniej nazwy stanowi więc element promocji, odróżnia (lub wyróżnia) przepis (i potrawę) spośród innych dostępnych w sieci, zachęca do jego wypróbowania i polecenia, przez co — ostatecznie - pomaga w budowaniu społeczności wokół wybranego bloga - marki (ale i społeczności wegan w ogóle).

\section{Kaban z kury i frytki z wołowiny}

„Zjawisko kontekstowego poszerzania zakresu nazw nie jest [...] cechą typową tylko dla wybranych, ściśle określonych leksemów [...] - dotyczy słownictwa kulinarnego jako całości”67. Oznacza to, że problem neosemantyzacji kulinarnych onimów, choć wyróżniany i komentowany jeśli chodzi o dania roślinne, w wypadku neosemantyzacji nazw potraw mięsnych zostaje niezauważony/przemilczany. O ile więc z jednej strony kabanos jak myśliwski (z seitana) ${ }^{68}$ albo kabanos sojowy bezglutenowy ${ }^{69}$ wzbudzają kontrowersje wśród mięsożernych, o tyle mało kto z nich pamięta, że kabanos (etymologicznie pochodzący od słowa kaban - 'wieprz') pierwotnie desygnował 'cienką, długą, obsuszaną kiełbasę wieprzową ${ }^{\text {'70 }}$. Tymczasem dziś na półkach sklepów można znaleźć (obok tradycyjnie wieprzowych) m.in. kabanosy drobiowe i wołowe. Podobnie definicja szynki, niegdyś odnosząca się do 'mięsa z tylnej części świni; także wędliny z tego mięsa ${ }^{71}$, aktualnie rozszerzona została do 'mięsa z tylnej części (uda)

${ }^{66}$ M. Dawidziak-Kładoczna, op. cit., s. 86. Ponadto, zachęcając do wypróbowania przepisu i przygotowania potrawy, w niektórych nazwach podkreśla się pragmatyczny aspekt (np. łatwość bądź szybkość) jej wykonania - proste kotlety marchewkowe z biała fasola (E, 7.02.2016), imbirowe kotleciki z ciecierzycy $w 15$ minut (E, 7.02.2016).

${ }^{67}$ M. Witaszek-Samborska, op. cit., s. 122.

68 Opis produktu na stronie sklepu „Urban Vegan”: „Dwa kabanosy [...] z seitanu smakiem i aromatem przypominające tradycyjne, a to wszystko za sprawą wyjątkowej kombinacji przypraw oraz dymu wędzarniczego" - www.urbanvegan.pl/kielbasy-i-parowki/4387-kabanos-jak-mysliwski-2szt-70g-heirler-4010318072398.html (dostęp: 5.06.2017).

${ }^{69}$ Produkt dostępny w tym samym sklepie - www.urbanvegan.pl/kielbasy-i-parowki/5252-kabanossojowy-bezglutenowy-40g-lord-of-tofu-4260019320735.html (dostęp: 5.06.2017).

70 Kabanos, [hasło w:] M. Jarosz, Słownik wyrazów obcych, red. I. Kamińska-Szmaj, Wrocław 2001, s. 346.

71 Szynka, [hasło w:] Inny słownik..., s. 772. 
półtuszy wieprzowej, wędliny z tego mięsa peklowanego i wędzonego lub z podobnej części innych zwierząt ${ }^{72}$ (co odzwierciedla dostępna na rynku oferta szynek: szynka z kurczaka, szynka wołowa czy szynka $z$ indyka, lecz także szynka sojowa).

Eksperymenty kulinarne, rozwój rynku gastronomii, popularność weganizmu oraz rozpowszechnianie się różnych ruchów żywieniowych (np. slow food) prowadzi do powstawania nie tylko zupełnie nowych nazw bądź słowotwórczych neologizmów, ale - nawet w większym stopniu - do generalizacji nazw już istniejących (neosemantyzmy). W ten sposób tak, jak nikogo dziś już nie dziwi wspomniany kabanos drobiowy albo sernik bez sera ${ }^{73}$ (przygotowywany na bazie śmietany lub jogurtu zamiast twarogu), tak też dziwić nie powinien kokosowy bekon, ryba $z$ selera, wegański łosoś (z marchwi) czy sernik $z$ nerkowców, zwłaszcza że coraz częściej odnotowuje się również mięsne wariacje na temat pierwotnie wegańskich potraw, np. czarny hummus (barwiony sepią) ${ }^{74}$ albo frytki mięsne (z wołowiny) $)^{75}$.

\section{Can fish be made of celery like pork made of chicken? On the names of dishes on vegan blogs (and tables)}

Summary

Recurring discussions, not only on the internet, about the names of vegetarian and vegan dishes drawing on the names of meat dishes (or dairy dishes) have become an inspiration for research which, I hope, will help answer the following question: "Can fish be made of celery like pork made of chicken?". Drawing on, among others, a lexicographic analysis of selected names, their neosemanticisation, functions of culinary onyms as well as the basic premises of general semantics, I will endeavour to present the motivation of the authors of the analysed blogs, which prompts them to assign to plant dishes names with connotations suggesting their animal origin.

72 Szynka, [hasło w:] Słownik nazw potraw..., s. 379.

73 Przykładowy przepis dostępny w Internecie na www.ciasta.net/sernik-bez-sera.php (dostęp: 3.06.2017).

${ }^{74}$ Czarny hummus jest przykładem nazwy potrawy, która może wprowadzić wegańskiego odbiorcę w błąd, ponieważ hummus z definicji jest potrawą roślinną ('arabska pasta z ciecierzycy, sezamu, oliwy i soku cytrynowego' (zob. Hummus, [hasło w:] Słownik nazw potraw..., s. 253), samo zaś jego dookreślenie czarny nie wskazuje bezpośrednio na element mięsny, odzwierzęcy (w tym przypadku sepię). Autor artykułu miał możliwość zaobserwowania takiej sytuacji w kwietniu 2017 r. na jednym z wernisaży we Wrocławiu.

75 M. Blatkiewicz, Frytki mięsne (Fat Bob Burger, Poznań), „Wygrywam z anoreksją, www.wygrywamzanoreksja.pl/na-miescie/poznan/frytki-miesne-fat-bob-burger-poznan/ (dostęp: 5.06.2017). Notabene blogera nie do końca przekonała nazwa potrawy (frytki), w związku z czym zaproponował, by danie nazwać (adekwatnie do wyglądu i smaku oraz przez konotacje do paluszków rybnych) paluszkami. 